ELORE (ISSN 1456-3010), vol. 19 - 1/2012.

Julkaisija: Suomen Kansantietouden Tutkijain Seura ry.

[http://www.elore.fi/arkisto/1_12/hynninen.pdf]

KIRJA-ARVIO

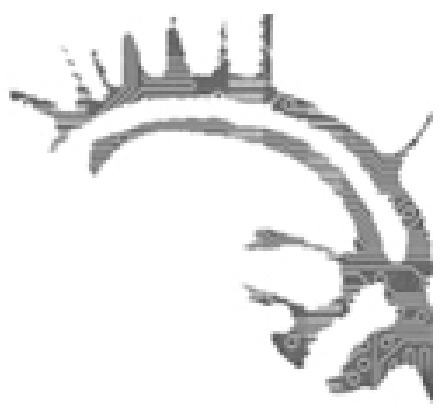

\title{
MITÄ RAKKAUS ON?
}

HATAKKA, MARI 2011: Nainen, mies, rakekaus, seksi. Heterosubteen kulku, kulttuurinen malli ja sitä selittävät diskurssit kahden omaelämäkerta-aineiston valossa. Helsinki: omakustanne. 364 sivua.

Anna Hynninen

Vaikka parisuhdetta pidetään yksilön yksityiseen elämään ja henkilökohtaisiin tunteisiin paikantuvana, se sisältää paljon jaettua kulttuurista tietoa ja normittavia rakenteita. Mari Hatakan folkloristiikan väitöskirja osoittaa, kuinka heteroseksuaalinen parisuhde on länsimaisessa yhteiskunnassa luonnollisena pidetty kulttuurinen konstruktio, ja kuinka 1900-luvulla Suomessa eläneillä ihmisillä on ollut laajasti katsottuna yhteinen ja jaettu käsitys siitä, millainen onnistuneen parisuhteen tulisi olla. Hatakan tutkimus käsittelee 1901-1965 välillä syntyneiden naisten ja miesten omaelämäkertojen sisältämiä parisuhdekuvauksia, joiden pohjalta tutkija hahmottaa heteroseksuaalisen parisuhteen kulttuurisen mallin eli skriptin rakennekomponentit sekä parisuhteen kerrontaa muovaavat vaihtelevat diskurssit. Omaelämäkerrat on poimittu kahdesta Suomalaisen Kirjallisuuden Seuran Kansanrunousarkiston järjestämästä kirjoituskilpailusta: Satasärmäinen nainen -elämäkertakirjoituskilpailu naisille (1990-1991) ja Eläköön mies -elämäkertakirjoituskilpailu miehille (1992-1993).

\section{KERUUELÄMÄKERRAN IDEAALITYYPIN HAHMOTTUMINEN LAAJAN AINEISTON AVULLA}

Hatakka kuvaa hyvin reflektiivisesti aineistonsa ja tutkimusasetelmansa muodostumisprosessia. Lopullinen aineisto on valikoitunut satunnaisotannalla, joka tukeutuu 


\section{Anna Hynninen: Mitä rakkaus on?}

vastaajien ikään ja sukupuoleen. Aineisto sisältää 98 omaelämäkertaa, joista 50 on naisen kirjoittamaa. Jokaisella vuosikymmenellä syntyneiden (1900-1960) kirjoittamista teksteistä on valikoitunut 13-16 omaelämäkertaa. Työn yhtenä vahvuutena näen Hatakan perehtyneisyyden aineistoon. Aineistoa on myös riittävästi suhteessa Hatakan sille asettamiin kysymyksiin. Hatakka määrittelee lukutavoikseen temaattisen luennan, intertekstuaalisen lähiluvun ja reflektiivisen lukutavan. Temaattisella luennalla Hatakka on hahmottanut ne tekstikohdat, jotka kertovat parisuhteen sisällöstä ja muodosta. Intertekstuaalisuudella Hatakka vuorostaan viittaa siihen, miten hän etsii omaelämäkerroista parisuhteen kulttuurisia merkityksiä, linkkejä ja viittauksia muihin kulttuurisiin teksteihin, jotka voivat olla kirjallisia, kuvallisia, musiikillisia tai toiminnallisia. Hatakka mainitsee intertekstuaalisuuden yhteydessä omaelämäkerrallisen kerronnan ja kaunokirjallisuuden väliset yhteydet, mutta hän viittaa myös laajemmin yhteiskunnallisten diskurssien vaikutukseen. Intertekstuaalisuuden lisäksi tai sijasta olisi tutkimukseen sopinutkin hyvin kontekstualisoinnin käsite, joka nostaa intertekstuaalisuutta paremmin esille yhteiskunnallisen ja kulttuurisen ulottuvuuden. Kun intertekstuaalisuus viittaa lähinnä eri tekstien välisiin yhteyksiin, viittaa kontekstuaalisuus myös tekstien ulkoisiin prosesseihin ja ilmiöihin sekä tutkijan merkitykseen kontekstualisoinnin tekijänä.

Hatakan tutkimuksessa omaelämäkerrat ovat sekä temaattisen analyysin lähteitä että itsessään yksi tutkimuksen fokuksista. Folkloristisessa tutkimuksessa kirjoitettuja elämäkerta-aineistoja koskeva metodologinen keskustelu on vasta aluillaan ja siksi työn yhtenä haasteena on useita eri perinnelajeja sisältävän genren folkloristinen määrittely. Hatakan hahmottelema kilpakeruuelämäkertojen genreanalyysi toimii työn lähdekritiikkinä onnistuneesti. Hatakka lähestyy kilpakeruuelämäkertoja kirjoitettuna perinteenä, omanlaisenaan "luonnollisena" lajina, joka eroaa muista elämäkerrallisen kirjoittamisen lajeista (toisen kirjoittamista muistelmista/elämäkerroista tai vain tiettyyn elämänvaiheiseen kohdistuvista muisteloista). Tutkimuksessa hahmottuu eräänlainen kilpakeruuelämäkerran ideaalityyppi, joka muodostuu konkreettisten kertomusten ja kertojan itsereflektion vuoropuhelusta.

Hatakka yhdistää työssään rohkealla tavalla kaksi erilaista teoriaperinnettä. Kognitiiviseen antropologiaan nojaavan skeemateorian avulla hän hahmottaa aineistosta eräänlaisen parisuhteen syvärakenteen, jonka hän näkee lähes annettuna tutkijan redusoitavissa olevana ja suhteellisen muuttumattomana mekanismina. Foucault'laisen diskurssiteorian avulla Hatakka vuorostaan pyrkii avaamaan yhdenmukaiselta näyttävää kulttuurista mallia monisyisemmäksi kulttuurisen ja henkilökohtaisen tiedon neuvottelukentäksi: kulttuurinen tieto ei täysin determinoi yksilöä, vaan hänellä on mahdollisuus parisuhteen esittämisen tapojen neuvotteluun. Tätä kautta foucault'laisen teoretisoinnin valinta on ymmärrettävissä. Valinta on kuitenkin riskialtis sikäli, että Foucault voidaan nähdä hyvinkin antikognitivistisena: Foucault'lle diskurssien takana ei ole mitään kognitiivista universaalia valmista rakennetta, jonka representaatio diskurssi olisi. Näin Hatakan valitsema skeemateoria sotii hieman foucault'laista perinnettä vastaan. Jokin toinen diskurssianalyysin suuntaus olisi saattanut teroittaa työn teoreettista osuutta. Nyt se jää melko etäiseksi ja pintapuoliseksi. 
Anna Hynninen: Mitä rakkaus on?

\section{KIHLOISTA HAUTAAN - MITÄ PARISUHTEESTA KERROTAAN JA MISTÄ VAIETAAN}

Analyysin ensimmäisellä tasolla Hatakka abstrahoi aineistosta parisuhteen toiminnallisen mallin, joka kuvaa tyypillistä käsitystämme parisuhteen kulusta puolison tapaamisesta eroon tai leskeytymiseen. Hatakka havainnollistaa analyysinsä etenemistä osuvin esimerkein ja osoittaa näin sen, että suurin variaatio tekstien välillä on sïnä, miten asioista kerrotaan, ei itse asioissa. Hatakan tutkimuksen kohdalla skriptin abstrahoiminen onkin vastannut yhteen työn pääkysymyksistä: mitä ihmiset kirjoittavat kulttuurisesta kategoriasta, parisuhteesta?

Analyysin toisessa vaiheessa Hatakka abstrahoi parisuhteen rakennekomponentit, joita ovat tutkimuksen mukaan rakkaus, seksuaalisuus, mies ja nainen. Jokainen komponenteista on tarpeellinen, jotta heteroseksuaalisen parisuhteen kulttuurinen malli Hatakan aineiston perusteella täyttyy. Ensimmäisenä Hatakka analysoi rakkautta. Hän paljastaa kokeneensa rakkauden teemakategorioista vaikeimmin analysoitavaksi, koska rakkaus tuntuu pakenevan kulttuurianalyysia. Toisena parisuhteen komponenttina Hatakka käsittelee seksuaalisuutta, jota kuvataan kirjoituksissa niukasti. Yllättävää onkin, että suurin osa aineistossa esiintyvistä seksuaalisuuden kuvauksista sijoittuu parisuhteen ulkopuoliseen seksuaalisuuteen. Miesten parisuhteen seksikuvaukset liittyvät kertojan ensimmäisiin sukupuolisiin kokemuksiin. Naisten seksuaalisuuden, halun ja naisen elämään kuuluvista fyysisten muutosten kerronta jää vuorostaan koko aineistossa hyvin niukaksi, mikä on herättänyt tutkijan pohtimaan sitä, onko kyse valikoituneesta kertojajoukosta vai niin voimakkaasta kulttuurisesta kiellosta, että vain harva nainen uskaltaa sitä uhmata? Lukijana jäin miettimään sekoittuvatko tutkimuksessa keskenään seksuaalisuns laajempana käsitteenä ja osana persoonallisuutta ja seksi toimintana. Ehkä käsitteiden tarkentaminen ja erottelu toisi esiin myös jonkinlaisia vivahteita naisten kerronnassa?

Kahtena viimeisenä parisuhteen komponenttina Hatakka analysoi miestä ja naista parisuhteessa. Luentansa avulla Hatakka osoittaa, miten parisuhdekerronta kuvaa käsityksiämme eri sukupuolista ja millaisia mieheyksiä ja naiseuksia aineistossa rakentuu. Yksi tutkimuksen mielenkiintoisista tuloksista on huomio siitä, miten sukupuolta korostetaan lähinnä silloin, kun kirjoitetaan konflikteista ja ongelmista. Ongelmat saattavat siis johtaa kuvittelemaan, että ne kumpuavat kumppanin vastakkaisesta sukupuolesta. Kun on tasaista tai auvoisaa aikaa, kiitos osoitetaan persoonalle ja yksilölle, ei sukupuolelle. Kiinnostavaa on, miten miehen luonnetta määrittelee käsitys suomalaisuudesta: suomalainen mies on kätevä käsistään, mutta ei näytä tunteitaan, jos näyttää, hän pussaa vaan ei puhu. Kietoutuvatko Hatakan aineistossa kansalaisuus ja sukupuoli toisiinsa vain miehen kohdalla, vai olisiko aineistosta määriteltävissä myös "tyypillinen" suomalainen nainen? Olisinkin toivonut kansalaisuuden ja sukupuolen yhteen kytkeytymisen pohdintaa hieman lisää. 


\section{HeteroseksuaAlisen PARISUHTEEN DiskURSsit}

Tutkimuksen lopussa Hatakka hahmottelee viisi erilaista parisuhdekuvauksista luettavaa diskurssia ja valtarakennetta, jotka ohjaavat diskursseja. Hatakan abstrahoimat diskurssit ovat hyvin yleistasoisia ja niiden voikin katsoa muodostavan eräänlaisen kulttuurintutkimuksellisen diskurssiapparaatin, joka on sovellettavissa myös muihin (omaelämäkerrallisiin) aineistoihin. Folkloristiikan kannalta mielenkiintoista on populaaritieteellisen ja kansanperinteen diskurssin osittainen lomittuminen. Populaaritieteellisen diskurssin auktoriteetti on median välittämä, helposti omaksuttava ja totuutena pidetty tiede, ja diskurssi soveltaa erityisesti luonnontieteen ja käyttäytymistieteen tietovarantoa. Kansanperinteen diskurssin auktoriteettina ovat usein vanhemmat, isovanhemmat, "vanhempi kansa", ja se vetoaa "ikiaikaisiin" totuuksiin ja itse koettuun. Kyseisten diskurssien välinen vertailu ansaitsisi lisähuomiota pohdittaessa ylipäätään perinteen muutosta sekä perinteen ja median yhteyttä.

Feministisen tutkimuksen kannalta mielenkiintoisimmaksi diskurssiksi nousee yhteiskunnallinen diskurssi, joka määrittelee naiseutta muun muassa tasa-arvoideologian, koulutuksen, työn ja avioliiton kautta. Aineiston perusteella lähes kaikki naiset ovat kokeneet epätasa-arvoa tai syrjintää, mutta samalla kukaan ei halua liittää tasa-arvoa feminismiin, mikä on kiinnostava ja ajankohtainen ilmiö edelleen 2010-luvulla. Hatakan mukaan yhteiskunnallinen diskurssi kumpuaa informanttien kokemuksista lausuttuina mielenilmauksina: yhteiskunnan kanssa ei olla samaa mieltä esimerkiksi naisen roolista äitinä tai miehen itsenäisestä asemasta yhteiskunnassa. Erilaiset yhteiskunnan edustajat esiintyvät vastapoolina pientä kirjoittavaa ihmistä vastaan. Tutkimuksessa olisi voinut nostaa tältä osin esiin enemmän kirjoittajien reaktioita valtarakennelmia kohtaan, jolloin yksi työn tavoitteista, kirjoitettujen kokemusten esiintuominen, olisi saanut enemmän jalansijaa. Esimerkiksi yksi työn kiinnostavimmista epätasa-arvoon liittyvistä huomioista liittyy siihen, miten yhteiskunnallinen diskurssi määrittelee naiseutta ja mieheyttä eri tavoin: naiseus märittyy yhteiskunnallisessa diskurssissa tasa-arvoideologian kautta, jolloin korostuvat sukupuolinen epätasa-arvo ja vastarinnaksi nousee toiminta erilaisissa naisasialiikkeissä. Miesten kohdalla yhteiskunnallinen diskurssi määrittelee miestä lähinnä taloudellisena toimijana, perheen elättäjänä ja näin tavallaan etupäässä luokkasidonnaisena, jolloin korostuu taloudellinen ja yhteiskunnallinen epätasa-arvo, luokkataistelut ja työväenliike.

\section{LOPUKSI}

Kirja etenee loogisesti ja kieli on rikasta sekä helppolukuista. Hatakka on sitonut analyysiinsä taidokkaasti kontekstuaalista tietoa ja onnistunut pidättäytymään oleellisessa, mikä on juuri kontekstualisoinnin suurimmista haasteista: mitä kaikkea taustainformaatiota ja intertekstuaalisia linkkejä tulee ottaa mukaan ja mitkä sulkeistaa tutkimuksesta ulos. Hatakka on perustellut valintansa selkeästi ja korostaa myös tutkijapersoonallisuutensa vaikutusta analyysiin. Ylipäätään aineiston käsittely on 
hyvin onnistunut ja runsaat aineistolainaukset selkiyttävät hyvin tulkintaa ja ovat näin perusteltavissa. Hatakka onnistuu myös tutkimuksensa varrella nostamaan esiin mahdollisia jatkokysymyksiä ja -tutkimusaiheita, mikä osoittaa tutkijan tiedostavan oman tieteenalansa ja tutkimusaiheensa kentän.

Tutkimusta olisi voinut syventää pohtimalla enemmän parisuhteen ajallista muutosta; olihan yksi tärkeimmistä aineiston muodostumiskriteereistä juuri vastaajien syntymävuosi. Käsitteiden ja analyysikategorioiden käytössä olisin myös toivonut tarkkuutta ja syventämistä. Esimerkiksi nainen ja naiseus tai seksi ja seksuaalisuus ovat toisistaan erotettavissa olevia kategorioita. Folkloristisen tutkimuksen ja ennen kaikkea keruuelämäkertojen luennan kannalta työn yksi hyödyllisimmistä anneista on elämäkertojen temaattisen analyysin havainnollistaminen: työ tuo hyvin esiin temaattisen luennan eri tasojen etenemisen ja luennan prosessuaalisuuden. Myös kerronnantutkimuksen ja yhteiskunta-analyysin yhdistäminen onnistuu työssä hyvin. Yleisemmällä tasolla ja akateemisen maailman ulkopuolella Hatakan tutkimusta voi pitää myös onnistuneena parisuhdetietopakettina, josta uskoisin olevan hyötyä omien ja läheistemme suhteiden käsittämisessä ja merkityksellistämisessä.

Filosofian maisteri Anna Hynninen on folkloristiikan jatko-opiskelija Turun yliopistossa. 